\title{
Sensitivity Evaluation of Two Human Breast Cancer Cell Lines to Tamoxifen through Apoptosis Induction
}

\author{
Spencer Keene, Charles Azuelos, Shyamal K. Majumdar* \\ Department of Biology, Lafayette College, Easton, PA, USA \\ Email: " \\ Received 13 September 2014; revised 15 October 2014; accepted 24 October 2014 \\ Copyright ( 2014 by authors and Scientific Research Publishing Inc. \\ This work is licensed under the Creative Commons Attribution International License (CC BY). \\ http://creativecommons.org/licenses/by/4.0/

(c) (i) Open Access

\section{Abstract}

Tamoxifen citrate (TAM) has been used to treat breast cancer in women for many years. The comparative effects of TAM in inducing apoptosis were evaluated in estrogen receptor-positive (ERpositive MCF-7) and estrogen receptor-negative (ER-negative MDA-MB-231) human breast cancer cell lines in vitro in order to determine if these two cell lines differ in their sensitivity to TAM. Mitochondrial membrane permeability potential disruption was assessed in both cell lines by a lipophilic cationic dye (DePsipher assay, Trevigen, Inc.) utilizing fluorescence microscopy. Using this specific fluorochrome, we were able to associate mitochondrial membrane disruption to early, mid-, and late apoptotic cells. TAM induced cell death via apoptosis in both ER-positive and ERnegative cells, however, apoptosis induction was more pronounced in ER-positive MCF-7 compared to ER-negative MDA-MB-231 breast cancer cells. These findings may have some therapeutic use in the treatment of estrogen dependent and estrogen independent breast cancer.

\section{Keywords}

Tamoxifen, Apoptosis, MCF-7 and MDA-MB-231 Human Breast Cancer Cell Lines, Mitochondrial Membrane Potential Assay, Estrogen Receptor

\section{Introduction}

Breast cancer is one of the leading causes of cancer-related deaths in human females, claiming 40,000 lives in 2013 alone [1]. In order to treat breast cancer, researchers have approached the disease from many different angles, including surgery, radiation, hormone therapy and chemotherapy. Tamoxifen (TAM) is one of these anti-

\footnotetext{
"Corresponding author.
}

How to cite this paper: Keene, S., Azuelos, C. and Majumdar, S.K. (2014) Sensitivity Evaluation of Two Human Breast Cancer Cell Lines to Tamoxifen through Apoptosis Induction. Open Journal of Apoptosis, 3, 70-77. 
estrogen hormones approved by the Food and Drug Administration (FDA) in 1977 to treat advanced and early stages of breast cancer [2]-[4]. TAM functions as an antagonist of the estrogen receptors of ER-positive (ER $\alpha+)$ breast cancer cells, leading to cell death via apoptosis, and thus lowering the risk of abnormal cell proliferation in the breast [5] [6]. TAM is a Selective Estrogen Receptor Modulator, also known as a SERM [7] [8]. SERMs function by binding to Estrogen Receptor-alpha $(\mathrm{ER} \alpha+)$, resulting in conformational changes in the receptor's structure [5] [6]. By competitively inhibiting the estrogen binding site, the cell is deprived of needed estrogen and does not proliferate as quickly [9]. Apoptosis occurs as a result of decreased proliferation in which cells accumulate in the $\mathrm{G}_{0}$ and $\mathrm{G}_{1}$ phases of cell division [10] [11]. TAM, however, is more effective in inducing apoptosis in ER $\alpha+$ breast cancer cells compared to ER $\alpha$-cells [12] [13]. In vitro studies have found that TAM acts as both a cytostatic and cytotoxic inhibitor of cell proliferation in breast and non-breast cancer cells [14] [15]. The ATR-ATM-TP53 pathway, in which the proteins ATR and ATM function, however, was not found to play a significant role in the Tamoxifen-induced apoptosis of ER $\alpha+$ cells [16].

While TAM acts as an estrogen inhibitor in breast cancer cells, it functions as estrogen in other parts of the body such as the uterus and bones, increasing the risk of developing cancer in these and other organs. When first released, Tamoxifen was a risk-classified drug, meaning the Food and Drug Administration (FDA) had determined it to be used only as a therapy for patients with advanced breast cancer [2]. Raloxifene, another SERM which has less side effects and works as well as TAM, was approved by the FDA for women who have an increased risk of developing breast cancer to mitigate TAM's toxic effects [17]-[19]. Studies involving TAM and Raloxifene alone and in combination in mice and in human females found anti-breast cancer effects in both drugs, although TAM was found to reduce the breast cancer risk more [20] [21]. Despite its associated risks, including uterine cancer and blood clotting, Tamoxifen remains the most widely used anti-estrogen chemotherapeutic drug for treating human breast cancer [3].

In this investigation, we studied two widely used human breast cancer cell lines, namely estrogen-positive MCF-7 and estrogen-negative MDA-MB-231, to evaluate if these two cell lines differ in their sensitivity to TAM in vitro. Both cell lines are invasive breast ductal carcinoma and grow as adherent cells. The generation time for MCF-7 is longer than that of MDA-MB-231 and MCF-7 grows in clustered clumps (luminal epithelium phenotype) compared to MDA-MB-231, which grows as flattened epithelial layers. While MCF-7 is an estrogen receptor-positive cell line, MDA-MB-231 lacks both estrogen and progesterone receptors, and contains a mutated form of the P53 tumor suppressor gene [22]. Earlier studies involving these two human breast cancer cell lines have shown enhanced sensitivity of estrogen receptor-positive MCF-7 cancer cells to TAM compared to the estrogen receptor-negative MDA-MB-231 cells [12] [13]. However, the difference in their cytotoxic sensitivity measured through TAM-induced programmed cell death, or apoptosis, is not firmly established. The purpose of this study was to investigate the cytotoxic sensitivity of ER-positive MCF-7 and ER-negative MDAMB-231 breast cancer cells exposed to different concentrations of TAM using a fluorescence-based assay to determine the functional status of mitochondria. Since mitochondria are generally known to be associated with early stages of apoptosis, in the present investigation we used a cationic dye purchased from Trevigen, Inc. (Gaithersburg, MD) to evaluate the status of mitochondrial membrane potential in healthy and apoptotic cells under a fluorescence microscope [23]. Our results revealed that ER $\alpha+$ MCF-7 cells were statistically more sensitive to TAM treatment compared to ER $\alpha$-MDA-MB-231 cells as evidenced from collated data obtained by enumerating early, mid- and late apoptotic cells. This difference, however, was more pronounced at the lower concentration $(2.5 \mu \mathrm{g} / \mathrm{mL})$. Although TAM-induced programmed cell death pointed towards a dose and time dependence, the differences, however, were not uniformly significant in this mitochondrial based assay.

\section{Materials and Methods}

\subsection{Cells and Cell Culture}

ER-positive MCF-7 and ER-negative MDA-MB-231 cells were provided by Dr. Robert Kurt, Department of Biology, Lafayette College (Easton, PA., USA). Cells were cultured in $25 \mathrm{~cm}^{2}$ tissue culture flasks (VWR Scientific, Bridgeport, NJ) in 4 mL Dulbecco's Modified Eagle's (DME) medium supplemented with 10\% Fetal Bovine Serum (DME-10) and 0.8\% penicillin and streptomycin (Gibco, Grand Island, NY) in a $37^{\circ} \mathrm{C}$ humidified incubator with $7.5 \% \mathrm{CO}_{2}$ in air.

\subsection{Cell Culture Preparation for Epiflourescence Microscopy}

Tamoxifen citrate (TAM) was purchased from Sigma Chemical Co. (St. Louis, MO., USA). The stock solution 
was prepared by dissolving $10 \mathrm{mg}$ of TAM in $0.1 \mathrm{~mL}$ of dimethyl sulfoxide (DMSO; Sigma Chemical Co; St. Louis, MO) then suspended in $10 \mathrm{~mL}$ of deionized water to a concentration of $1 \mathrm{mg} / \mathrm{mL}$. Approximately 100,000 cells/mL were seeded on sterile cover slips and placed in $35 \mathrm{~mm}$ petri plates containing $2 \mathrm{~mL}$ of DME-10 medium and 2.5 or $5 \mu \mathrm{g} / \mathrm{mL}$ TAM. Cells were counted using a hemacytometer and trypan blue exclusion assay. The control groups received a similar amount of sterilized deionized water containing the appropriate amount of DMSO without the TAM. The petri plates were placed in a humidified incubator of $7.5 \% \mathrm{CO}_{2}$ in air. Both stocks (TAM and control) were stored at -20 degrees $\mathrm{C}$. The experiment was repeated three to four times for each control and treatment group.

\subsection{Mitochondrial Transmembrane Potential Disruption Detection}

Mitochondrial membrane potential breakdown was detected using a DePsipher assay kit containing a lipophilic cationic stain (Trevigen, Inc., Gaithersburg, MD, USA). Slides were prepared following Trevigen's protocol. In healthy cells where mitochondrial membrane potential is active, the dye readily enters and aggregates in the transmembrane and fluoresces red/orange. In dying and dead cells, where mitochondrial membrane potential has collapsed, the DePsipher dye cannot accumulate within the mitochondria. The stain retains its green monomeric form and cells fluoresce green [24]. Both apoptotic and healthy cells in treated and untreated samples were classified on the basis of fluorescing color under a Nikon Eclipse E800 confocal/epifluorescence microscope using DAPI-FITC-TRITC wide band-pass filter. Cells were designated live, dying, or dead based on their fluorescence color. The latter two cell types were scored as being apoptotic. At least 1500 cells were counted randomly for each treatment and duration.

\subsection{Data Analysis}

Data were analyzed using a two-tailed unequal variance Student's T-Test and F-Test [25]. All statistics and graphs were calculated and constructed using Microsoft Excel 2007.

\section{Results}

Mitochondrial membrane potential disruption assay detected significantly more TAM-induced apoptosis in both MCF-7 estrogen receptor-positive and MDA-MB-231 estrogen receptor-negative breast cancer cells relative to untreated cells in both 2.5 and $5 \mu \mathrm{g} / \mathrm{mL}$ concentrations at all three treatment durations (Table 1). Cell death via apoptosis was identified using a lipophilic cationic dye present in the DePsipher assay kit purchased from Trevigen, Inc. The apoptotic cells were distinguished on the basis of color emitted both from cells and mitochondria under an epifluorescence microscope. For example, in cells where mitochondrial membrane potential is active, the mitochondria fluoresced an orange-red color (Figures $1(\mathrm{~A})-(\mathrm{F})$ ), and cells where mitochondrial potential is disrupted the cells and mitochondria appeared green (Figure 1(B), Figure 1(C), Figure 1(E), Figure 1(F)). At mid-apoptotic stage, the cells and mitochondria emitted both green and red-orange (Figure 1(B)). Untreated cells for both breast cancer cell lines, irrespective of time, remained more or less similar in viability, ranging from $92 \%$ to $97 \%$. TAM significantly increased programmed cell death in MCF-7 compared to MDA-MB-231 (Table 1). This difference was found to be consistently significant in Student's T-test $(\mathrm{p} \leq 0.05)$ at $2.5 \mu \mathrm{g} / \mathrm{mL}$ at all treatment durations (Figure 2). At $5 \mu \mathrm{g} / \mathrm{mL}$, the difference was significant at the 48 and 72 hours treatment periods (Table 1).

Although the mitochondrial membrane potential breakdown in response to TAM showed an increasing trend in a concentration and time dependant manner, the differences were not significant at all points (Table 1). The results obtained at each interval are also summarized in graphical form in Figure 2.

\section{Discussion}

Tamoxifen (TAM), a Selective Estrogen Receptor Modulator (SERM) is the most widely used anti-breast cancer drug in humans [26]. It was first used as an anti-estrogenic drug to treat estrogen receptor-positive breast cancer [5] [7]. By blocking estrogen receptors, TAM arrests cells in the $G_{1}$ phase and induces cell death via apoptotic pathways [5] [7] [27]. Subsequent studies have revealed that TAM can also inhibit cell proliferation and induce apoptosis in certain estrogen receptor-negative breast cancer cells through inhibition of protein kinase $C$ and via the caspase-3 and JNK1 pathways [10] [26]. Since information on TAM-induced apoptosis in ER-negative 

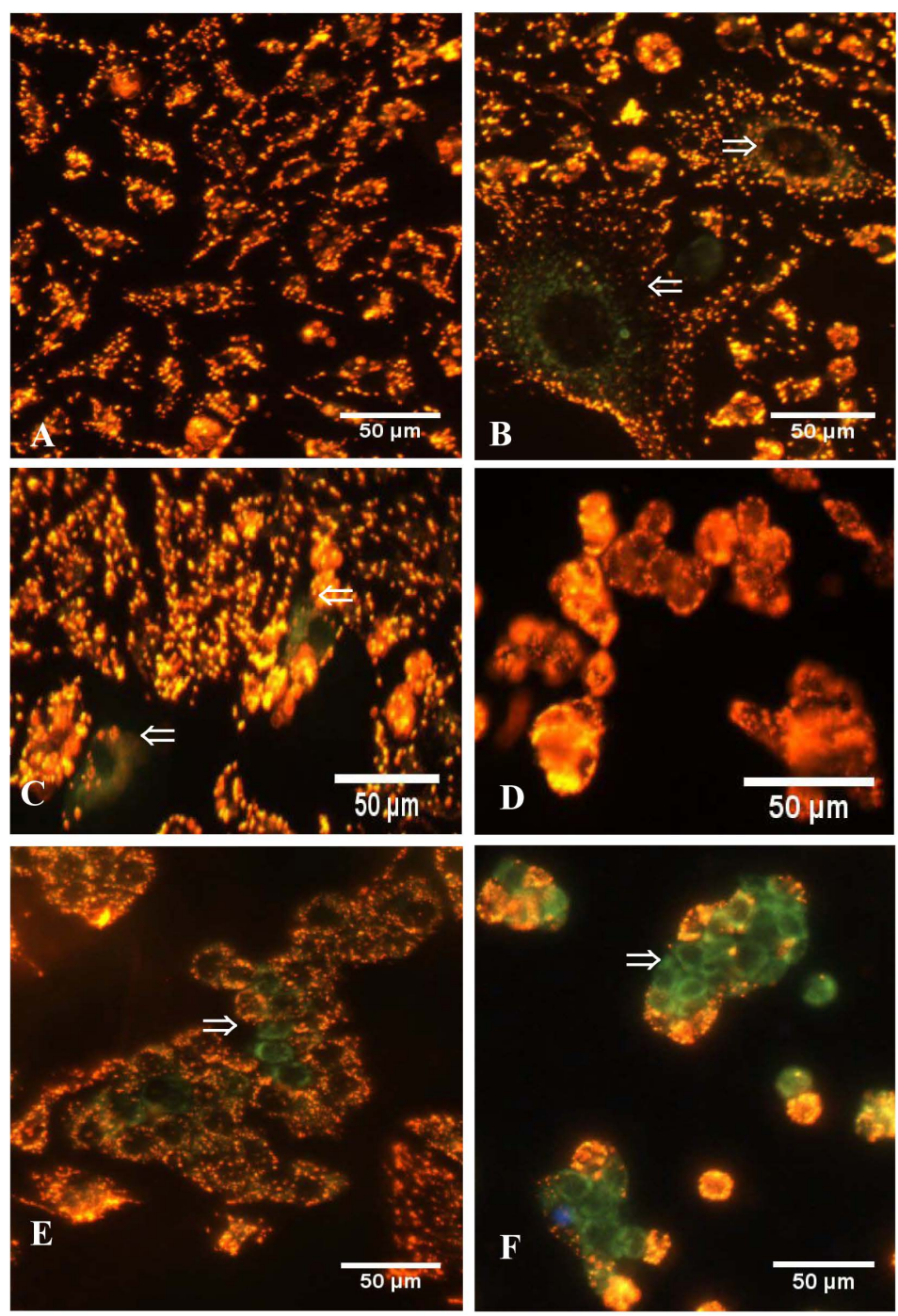

Figure 1. Epifluorescence photomicrographs of MDA-MB-231 (A-C) and MCF-7 (D-F) breast cancer cells treated with TAM. Micrographs show scale bar in microns. (A) and (D) are untreated MDA-MB-231 and MCF-7 showing orange/red mitochondria and cells. (B) $(2.5 \mu \mathrm{g} / \mathrm{mL})$ and (C) $(5 \mu \mathrm{g} / \mathrm{mL})$ TAM treated MDA-MB-231 cells showing a few green patches or apoptotic cells (arrows). (B) shows two giant cells at mid-apoptotic stage (red/orange/green mitochondria). Late apoptotic stages are visible in treated MCF-7 cells: (E) $2.5 \mu \mathrm{g} / \mathrm{mL}$ and (F) $5 \mu \mathrm{g} / \mathrm{mL}$.

Table 1. Apoptosis induction in MCF-7 and MDA-MB-231 cells exposed to two Tamoxifen concentrations.

\begin{tabular}{|c|c|c|c|c|c|c|c|c|}
\hline \multicolumn{5}{|c|}{ MCF-7 } & \multicolumn{4}{|c|}{ MDA-MB-231 } \\
\hline \multicolumn{4}{|c|}{ \% Apoptotic Cells } & & \multicolumn{4}{|c|}{ \% Apoptotic Cells } \\
\hline Control & $5 \mu \mathrm{g} / \mathrm{mL}$ & Control & $2.5 \mu \mathrm{g} / \mathrm{mL}$ & Hours & Control & $5 \mu \mathrm{g} / \mathrm{mL}$ & Control & $2.5 \mu \mathrm{g} / \mathrm{mL}$ \\
\hline $2.98 \pm 1.3$ & $19.53 \pm 1.95 \Delta$ & $7.84 \pm 1.19$ & $23.54 \pm 3.99^{*}$ & 24 & $7.95 \pm 1.51$ & $15.42 \pm 1.27 \Phi$ & $4.54 \pm 2.67$ & $8.56 \pm 1.03^{*} \Phi$ \\
\hline $5.99 \pm 1.49$ & $39.43 \pm 3.35^{*}$ & $3.76 \pm 0.53$ & $32.01 \pm 4.14^{*}$ & 48 & $4.81 \pm 0.93$ & $19.04 \pm 3.91^{*}$ & $1 \pm 0.03$ & $9.72 \pm 2.96^{*}$ \\
\hline $7.91 \pm 0.89$ & $45.41 \pm 7.64^{*} \Phi$ & $4.35 \pm 1.07$ & $25.22 \pm 1.67^{*} \Phi$ & 72 & $7.02 \pm 2.20$ & $20.67 \pm 9.45^{*}$ & $1.12 \pm 0.25$ & $11.31 \pm 1.86^{*}$ \\
\hline
\end{tabular}

Apoptotic percentages were calculated by counting both dead (green) and dying cells (orange/red/green) together. Estrogen receptor-positive MCF-7 cells were more sensitive to TAM compared to estrogen receptor-negative MDA-MB-231 at each concentration and time point. Apoptotic percentages that were significantly different between the two cell lines were identified with the star symbol $\left({ }^{*}\right)$. Significant difference in programmed cell death resulted from the higher and lower concentration treatments were denoted with phi $(\Phi)$ symbol. Time dependence was indicated by the delta $(\Delta)$ symbol for significance between 24 and 48 hours and between 24 and 72 hours. Time dependence was only observed in MCF-7 cells at 5T concentration. Symbol \pm represents standard error of the mean. 

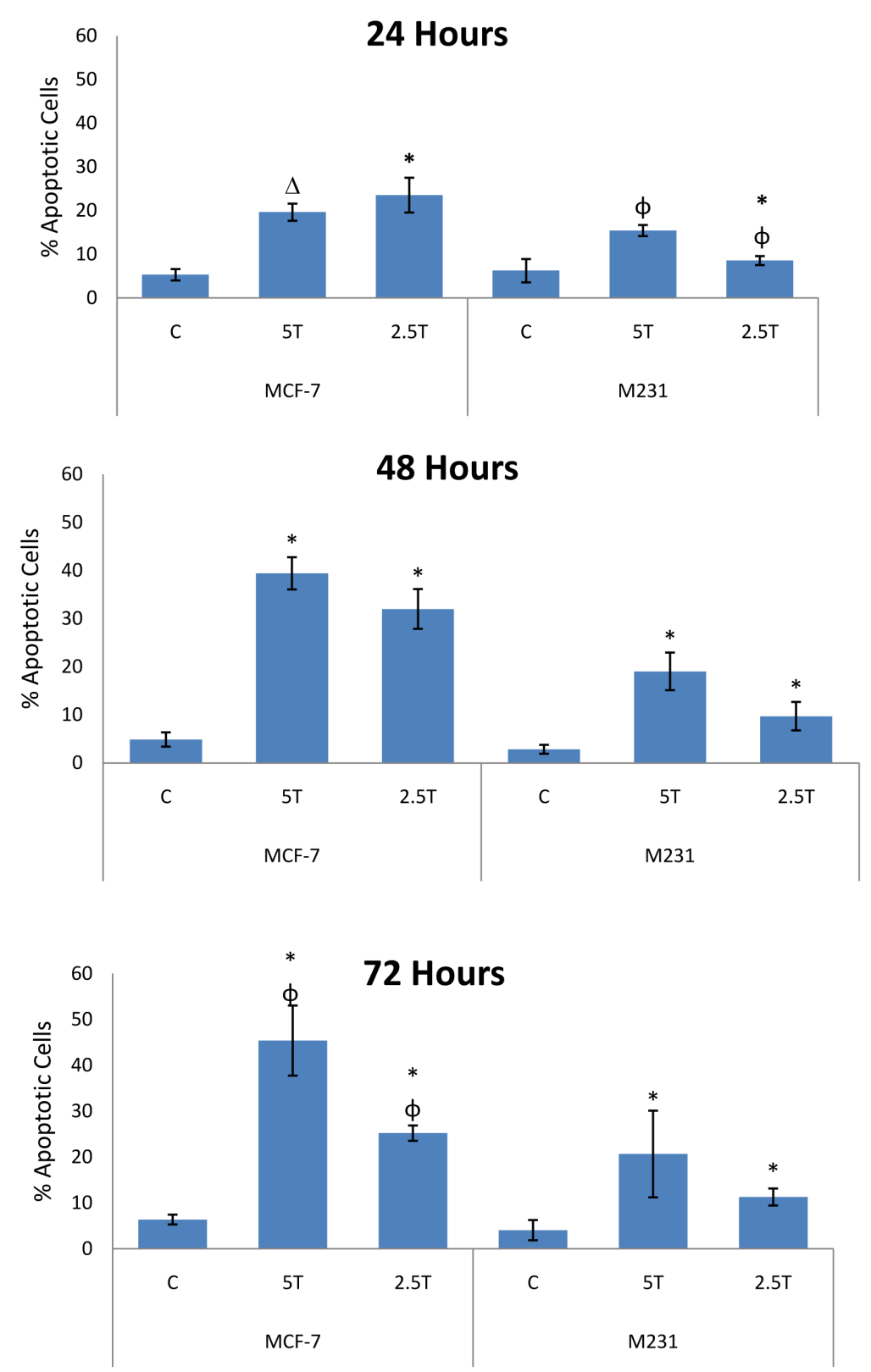

Figure 2. Comparison of apoptosis induction between MCF-7 and MDA-MB-231 (M231) breast cancer cells at different TAM concentrations. At each concentration and time point MCF-7 cells showed more apoptosis induction than MDAMB-231 cells. Apoptotic cell percentages that are significantly different are identified with the symbol* . Significant treatment differences between $5 \mathrm{~T}$ and $2.5 \mathrm{~T}$ concentrations are noted with the $\varphi$. Time dependence is indicated by $\Delta$ for significance between 24 and 48 hours and between 24 and 72 hours \pm represents standard error of the mean.

breast cancer cells via different pathways is limited, further studies on the mechanisms of apoptosis induction in $\mathrm{ER}+$ and ER- breast cancer cells are warranted. Mitochondrial function determination was one of the pathways used in this investigation for detection of apoptosis induction. Mitochondrial membrane potential disruption is considered an early event in the apoptotic pathway in many cell systems, although it may not be universal [23] [28].

In this study, we explored the existence of a possible sensitivity difference between estrogen dependent (MCF-7+) and estrogen independent (MDA-MB-231-) human breast cancer cell lines to Tamoxifen citrate (TAM) in vitro utilizing a mitochondrial membrane potential disruption assay. We used an epifluorescence microscope to identify apoptotically-induced dying and dead cells. It is known that apoptosis induction in response 
to many toxic chemicals is mediated via the formation of mitochondrial membrane pores, resulting in the disruption of the mitochondrial membrane potential [23]. The lipophilic stain (DePsipher) used in this study was sensitive to membrane disruption detection allowing visual distinction of dying, dead, and live cells.

Cell death via apoptosis occurred irrespective of the presence or absence of estrogen receptors in these two breast cancer cell lines. TAM induced significantly more programmed cell death at both 2.5 and $5 \mu \mathrm{g} / \mathrm{mL}$ concentrations at all three treatment durations compared to their respective untreated controls. Between the two cell lines, however, ER+ MCF-7 cells exhibited more sensitivity to TAM's cytotoxic effects when compared to estrogen-independent MDA-MB-231 cells, and this difference was statistically significant at most data points. McFadden and Majumdar reported similar sensitivity difference in these two cell lines exposed to different concentrations of TAM on cell proliferation, viability and clonability [13]. Our findings are also in agreement with an earlier study where TAM elicited more apoptosis in estrogen receptor-positive MCF-7 breast cancer cells compared to estrogen independent MDA-MB-231 cells [29].

TAM induces apoptosis via the release of the mitochondrial cytochrome c, a decrease of mitochondrial membrane potential, and an increase in production of reactive oxygen species (ROS) [30]-[32]. An increase in ROS can cause caspase activation. This involves the release of cytochrome c from the mitochondria, which forms an apoptosome complex activating procaspase 9 leading to mitochondrial apoptosis [6]. Release of cytochrome $\mathrm{c}$ is facilitated by mitochondrial permeability transition, which occurs when the electrochemical gradient across the mitochondrial membrane collapses. This collapse takes place through the formation of channels or pores in the mitochondrial membrane. Acute TAM toxicity was weakened when MCF-7 cells were treated with bongkrekic acid, an inhibitor of mitochondrial membrane permeability transition process [33].

In this study, programmed cell death differences as a result of TAM exposure might be due to genetic differences between the two cell lines. The MCF-7 breast cancer cells are ER-positive with low expression of HER2 receptors, while MDA-MB-231 breast cancer cells are triple negative, lacking receptors for both estrogen and progesterone and containing a mutated form of the P53 tumor suppressor gene [22] [33]-[36]. Table 1 shows that a smaller dose of TAM was sufficient to induce apoptosis in ER-positive MCF-7 cells to a greater number compared to ER-negative MDA-MB-231 which would have required a substantially increased dose of the drug to reach a smilar value. It is known that TAM-induced apoptosis in certain ER-negative breast cancer is ER-independent, and it is accomplished through the activation of certain caspase proteases and inhibition of protein kinase C [10] [11] [26]. Kallio et al. have shown that MCF-7 and MDA-MB-231cells undergo apoptosis as a non-specific, non-genomic response to TAM [33].

The present study has shown that breast cancer cells are sensitive to TAM; however, previous studies have noted that TAM cytotoxicity can occur in normal cells and that the drug can cause cellular transformation leading to cancer initiation [37] [38]. TAM's specific apoptotic pathway raises questions about its effects on the metabolic profile of breast cancer cell lines. A recent study has shown that untreated triple-negative breast cancer cells already exhibited a compromised mitochondrial electron transport chain pathway and were more dependent on glycolysis than other breast cancer cells such as MCF-7. Additionally, untreated MDA-MB-231 cells maintain a higher mitochondrial transmembrane potential than MCF-7 cells [39]. Therefore, any detailed comparison of mitochondrial activities affected by treatment of TAM is a subject of future investigation.

Even though apoptosis increased in both a time and concentration dependent manner in each cell line, the differences were not uniformly significant in this mitochondrial assay system. Additional studies are required to resolve this issue. In conclusion, this investigation, utilizing a mitochondrial membrane potential disruption assay, demonstrated that TAM induced apoptosis in both estrogen receptor-positive MCF-7 and estrogen receptor-negative MDA-MB-231 breast cancer cells. Apoptosis induction, however, was more pronounced in the estrogen dependant MCF-7cell line, which was found to be statistically different from the estrogen independent MDA-MB-231 cell line.

\section{Acknowledgments}

The authors thank the Roger Newton Student Research Fund and the Lafayette College Biology Department for providing funds for the study.

\section{References}

[1] National Cancer Institute at the National Institute of Health (2014) http://www.cancer.gov/cancertopics/types/breast 
[2] U.S. Food and Drug Administration: Center for Drug Evaluation and Research (1977) FDA Oncology Tools Approval Summary for Tamoxifen. http://www.accessdata.fda.gov/scripts/cder/onctools/summary.cfm?ID=61

[3] Friedman, M.A. (1998) Tamoxifen. Statement of Lead Deputy Commissioner, FDA, US Department of Health and Human Services before Congressional Caucus for Women's Issues. http://www.fda.gov/NewsEvents/Testimony/ucm115118.htm.

[4] Wozniak, K., Kolacinska, A., Blasinka-Morawiek, M., Morawiek-Bajda, A., et al. (2007) The DNA-Damaging Potential of Tamoxifen in Breast Cancer and Normal Cells. Archives of Toxicology, 81, 519-527. http://dx.doi.org/10.1007/s00204-007-0188-3

[5] MacGregor, J.I. and Jordan, V.C. (1998) Basic Guide to the Mechanisms of Antiestrogen Action. Pharmacology Review, 50, 151-196.

[6] Obrero, M., Yu, D. and Shapiro, D. (2002) Estrogen Receptor-Dependent and Estrogen Receptor-Independent Pathways for Tamoxifen and 4-Hydroxytamoxifen-Induced Programmed Cell Death. Joural of Biological Chemistry, 277, 45695-45703. http://dx.doi.org/10.1074/jbc.M208092200

[7] Jordan, V.C. (1998) Designer Estrogens. Scientific American, 297, 60-67. http://dx.doi.org/10.1038/scientificamerican1098-60

[8] Renoir, J.M., Bouclier, C., Seguin, A., Marsad, V. and Sola, B. (2008) Antioestrogen-Mediated Cell Cycle Arrest and Apoptosis Induction in Breast Cancer and Multiple Myeloma Cells. Journal of Molecular Endocrinology, 40, 101-112. http://dx.doi.org/10.1677/JME-07-0143

[9] Goetz, M., Schaid, D., Wickerham, D., Safgren, S., Mushiroda, T., Kubo, M., Batzler, A., Costantino, J., Vogel, V.G., Paik, S., Carlson, E., Flockhart, D., Wolmark, N., Nakamura, Y., Weinshilboum, R., Ingle, J. and Ames, M. (2012) Evaluation of CYP2D6 and Efficacy of Tamoxifen and Raloxifene in Women Treated for Breast Cancer Chemoprevention: Results from the NSABP P-1 and P-2 Clinical Trials. Clinical Cancer Research, 17, 6944-6951. http://dx.doi.org/10.1158/1078-0432.CCR-11-0860

[10] Mandlekar, S., Yu, R. and Tan, T.H. (2000) Activation of Caspase-3 and c-Jun $\mathrm{NH}_{2}$-Terminal Kinase-1 Signaling Pathways in Tamoxifen-Induced Apoptosis of Human breast Cancer Cells. Cancer Research, 60, 5995-6000.

[11] Mandlekar, S. and Kong, A.N.T. (2001) Mechanisms of Tamoxifen-Induced Apoptosis. Apoptosis, 6, 469-477. http://dx.doi.org/10.1023/A:1012437607881

[12] Salami, S. and Karami-Tehrani, F. (2003) Biochemical Studies of the Apoptosis Induced by Tamoxifen in Estrogen Receptor Positive and Negative Breast Cancer Cell Lines. Clinical Biochemistry, 36, 247-253. http://dx.doi.org/10.1016/S0009-9120(03)00007-9

[13] McFadden, P. and Majumdar, S.K. (2012) Differential Sensitivity Evaluation of MCF-7 and MDA-MB-231 Human Breast Cancer Cells Exposed to Tamoxifen Alone and in Combination with Estradiol. International Journal Pharma and Bio-Science, 3, 541-548.

[14] Perry, R., Kang, Y. and Greaves, B. (1995) Effects of Tamoxifen on Growth and Apoptosis of Estrogen-Dependent and -Independent Human Breast Cancer Cells. Annals of Surgical Oncology, 2, 238-245. http://dx.doi.org/10.1007/BF02307030

[15] Majumdar, S.K., Valdellon, J.A. and Brown, K.A. (2001) In Vitro Investigations on the Toxicity and Cell Death Induced by Tamoxifen on Two Non-Breast Cancer Cell Types. Journal of Biomedicine and Biotechnology, 1, 99-107. http://dx.doi.org/10.1155/S1110724301000316

[16] Hasan, N., Kurt, R. and Majumdar, S.K. (2012) Investigation of the Roles of ATM and ATR in Tamoxifen-Induced Apoptosis in 4T1 Mouse Breast Cancer Cells. International Journal of Life Science and Pharma Research, 2, 304-320.

[17] Deal, C. and Draper, M. (2006) Raloxifene: A Selective Estrogen-Receptor Modulator for Postmenopausal Osteoporosis: A Clinical Update on Efficacy and Safety. Women's Health, 2, 199-210. http://dx.doi.org/10.2217/17455057.2.2.199

[18] Habel, L.A., Pressman, A., Ettinger, B., Sidney, S., Suh-Burgmann, B., Fehrenbacher, L. and Quesenberry, C.P. (2006) Use of Raloxifene among Women with a History of Breast Cancer. Breast Cancer Research and Treatment, 96, 123129. http://dx.doi.org/10.1007/s10549-005-9069-8

[19] Vogel, V.G. (2009) The NSABP Study of Tamoxifen and Raloxifene (STAR) Trial. Expert Review of Anticancer Therapy, 9, 51-60. http://dx.doi.org/10.1586/14737140.9.1.51

[20] Baum, M., Budzar, A.U., Cuzick, J., Forbes, J., Houghton, J.H., Klijn, J.G. and Sahmoud, T. (2002) Anastrozole Alone or in Combination with Tamoxifen versus Tamoxifen Alone for Adjuvant Treatment of Postmenopausal Women with Early Breast Cancer: First Results of the ATAC Randomised Trial. The Lancet, 359, 2131-2139. http://dx.doi.org/10.1016/S0140-6736(02)09088-8

[21] Xanthopoulos, J.M., Romano, A.E. and Majumdar, S.K. (2005) Response of Mouse Breast Cancer Cells to Anastrozole, Tamoxifen and the Combination. Journal of Biomedicine Biotechnology, 1, 10-19. 
http://dx.doi.org/10.1155/JBB.2005.10

[22] Thompson, E.W., Reich, R., Shima, T.B., Albini, A., Graf, J., Martin, G.R., Dickson, R.B. and Lippman, M.E. (1988) Differential Regulation of Growth and Invasiveness of MCF-7 Breast Cancer Cells by Antiestrogens. Cancer Research, 48, 6764-6768.

[23] Zamzami, N., Marchetti, P., Castedo, M., Hirsh, T., Susin, S.A., Masse, B. and Kroemer, G. (1996) Inhibitors of Permeability Transition Interfere with the Disruption of the Mitochondrial Transmembrane Potential during Apoptosis. FEBS Letters, 384, 53-57. http://dx.doi.org/10.1016/0014-5793(96)00280-3

[24] DePsipher ${ }^{\mathrm{TM}}$ Kit. Trevigen, Inc. (2014) http://www.trevigen.com/item/3/14/94/621/DePsiphertrade_Kit/

[25] Snedecor, G.W. (1956) Statistical Methods. Iowa State University Press, Iowa.

[26] Gelmann, E.P. (1996) Tamoxifen Induction of Apoptosis in Estrogen Receptor-Negative Cancers: New Tricks for an Old Dog? Journal of the National Cancer Institute, 88, 224-226. http://dx.doi.org/10.1093/jnci/88.5.224

[27] Mantena, S.K., Sharma, S.D. and Katiyar, S.K. (2006) Berberine Inhibits Growth, Induces G ${ }_{1}$ Arrest and Apoptosis in Human Epidermoid Carcinoma A431 Cells by Regulating Cdki-Cdk-Cyclin Cascade, Disruption of Mitochondrial Membrane Potential and Cleavage of Caspase 3 and PARP. Carcinogenesis, 27, 2018-2027. http://dx.doi.org/10.1093/carcin/bgl043

[28] Ly, J.D., Grubb, D.R. and Lawen, A. (2003) The Mitochondrial Membrane Potential ( $\left.\Delta \psi_{\mathrm{m}}\right)$ in Apoptosis; an Update. Apoptosis, 8, 115-128. http://dx.doi.org/10.1023/A:1022945107762

[29] Ellis, P.A., Saccani-Jott, G., Clarke, R., Johnston, S.R.D., Anderson, E., Howell, A., A'Hern, R., Saltar, J., Detre, S., Nicholson, R., Robertson, J., Smith, I.E. and Dowsett, M. (1997) Induction of Apoptosis by Tamoxifen and ICI 192780 in Primary Breast Cancer. International Journal of Cancer, 72, 608-613. http://dx.doi.org/10.1002/(SICI)1097-0215(19970807)72:4<608::AID-IJC10>3.0.CO;2-7

[30] Sutherland, R., Hall, R. and Taylor, I. (1983) Cell Proliferation Kinetics of MCF-7 Human Mammary Carcinoma Cells in Culture and Effects of Tamoxifen on Exponentially Growing and Plateau-Phase Cells. Cancer Research, 43, 39984006.

[31] Singh, B., Bhat, N. and Bhat, H. (2011) Partial Inhibition of Estrogen-Induced Mammary Carcinogenesis in Rats by Tamoxifen: Balance between Oxidant Stress and Estrogen Responsiveness. PLoS ONE, 6, 1-11. http://dx.doi.org/10.1371/journal.pone.0025125

[32] Guo, W., Shiina, I., Wang, Y., Umeda, E., Watanabe, C., Uetake, S., Ohashi, Y., Yamori, T. and Dan, S. (2013) Ridaifen-SB8, a Novel Tamoxifen Derivative, Induces Apoptosis via Reactive Oxygen Species-Dependent Signaling Pathway. Biochemical Pharmocology, 86, 1272-1284. http://dx.doi.org/10.1016/j.bcp.2013.08.020

[33] Kallio, A., Zheng, A., Dahllund, J., Heiskanen, K. and Harkonen, P. (2005) Role of Mitochondria in Tamoxifen Induced Rapid Death of MCF-7 Breast Cancer Cells. Apoptosis, 10, 1395-1410. http://dx.doi.org/10.1007/s10495-005-2137-Z

[34] Hui, L., Zheng, Y., Yan, Y., Bargonetti, J. and Foster, D.A. (2006) Mutant p53 in MDA-MB-231 Breast Cancer Cells Is Stabilized by Elevated Phospholipase D Activity and Contributes to Survival Signals Generated by Phosopholipase D. Oncogene, 25, 7305-7310. http://dx.doi.org/10.1038/sj.onc.1209735

[35] Lin, V.C., Jin, R., Tan, P.H., Aw, S.E., Woon, C.T. and Bay, B.H. (2003) Progesterone Induces Cellular Differentiation in MDA-MB-231 Breast Cancer Cells Transfected with Progesterone Receptor Complementary DNA. American Journal of Pathology, 162, 1781-1787. http://dx.doi.org/10.1016/S0002-9440(10)64313-1

[36] Al Amri, W.S., Balachandran, I., Thangirala, S., Coleman, A., El-Fawal, H.A.N. and Mousa, S.A. (2013) Differential Association between HER2/Neu and Angiogenesis in Breast Cancer. American Journal of Cancer Biology, 1, 1-15.

[37] Petinari, L., Kohn, L.K., de Carvalho, J.E. and Genari, S.C. (2004) Cytotoxicity of Tamoxifen in Normal and Tumoral cel Lines and Its Ability to Induce Cellular Transformation in Vitro. Cell Biology International, 28, 531-539. http://dx.doi.org/10.1016/j.cellbi.2004.04.008

[38] Shehata, M., van Amerongen, R., Zeeman, A.L., Giraddi, R.R. and Stingl, J. (2014) The Influence of Tamoxifen on Normalmouse Mammary Gland Homeostasis. Breast Cancer Research, 16, 411-421. http://dx.doi.org/10.1186/s13058-014-0411-0

[39] Pelicano, H., Zhang, W., Jinyun, L., Hammoudi, N., Dai, J., Rui-Hua, X., Lajos, P. and Huang, P. (2014) Mitochondrial Dysfunction in Some Triple-Negative Breast Cancer Cell Line: Role of mTOR Pathway and Therapeutic Potential. Breast Cancer Research, 434, 1-16. 
Scientific Research Publishing (SCIRP) is one of the largest Open Access journal publishers. It is currently publishing more than 200 open access, online, peer-reviewed journals covering a wide range of academic disciplines. SCIRP serves the worldwide academic communities and contributes to the progress and application of science with its publication.

Other selected journals from SCIRP are listed as below. Submit your manuscript to us via either submit@scirp.org or Online Submission Portal.
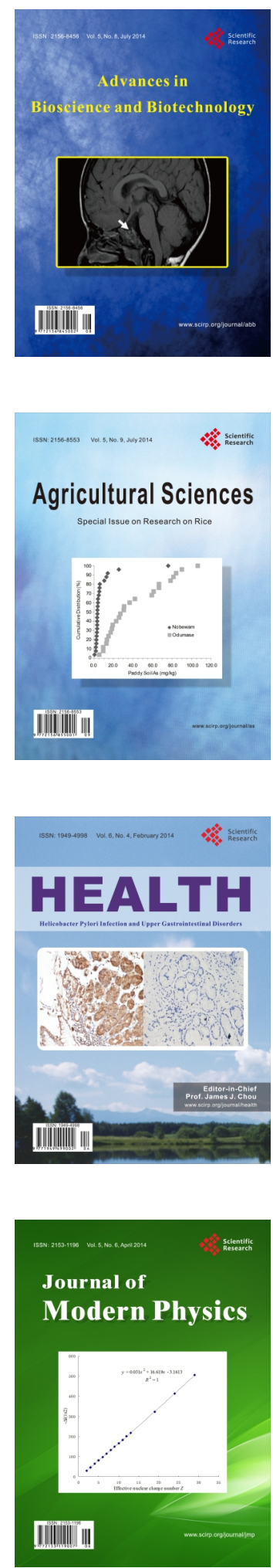
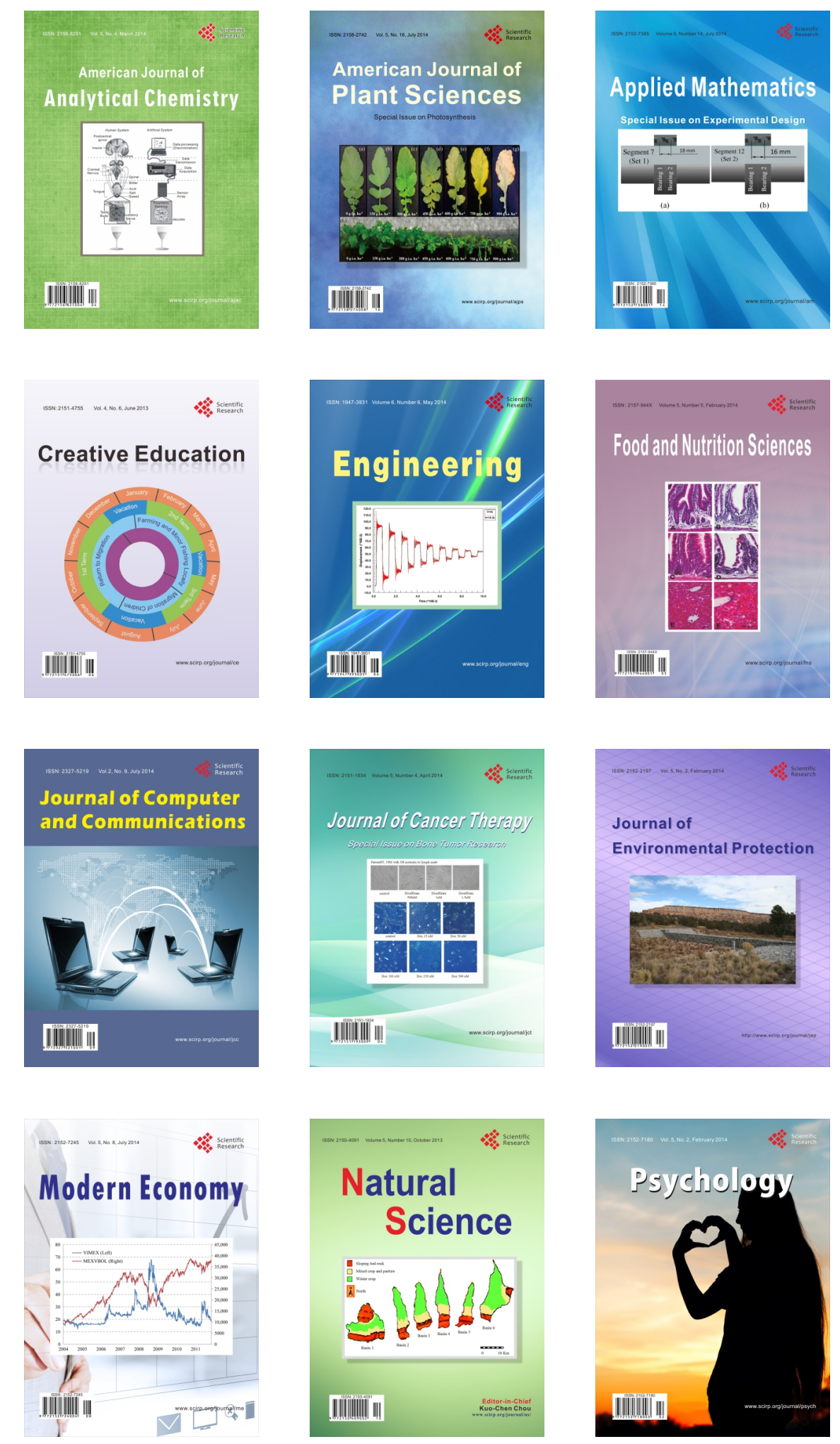